\title{
Visual Communications and Learning
}

\author{
Seda Khadimally \\ University of Phoenix, Arizona, USA
}

\begin{abstract}
Visual representation of content during the design and delivery of instruction emerges as an integral component of the process. Use of visuals that helps transmit a certain message to learners or users of a particular instructional or an industrial product plays a crucial role in active learning. From a pedagogical viewpoint applied in learning and teaching, when learners are provided with a solid instructional product, they get to actively engage in the learning activities with higher cognitive process and apply their newly gained knowledge in real-life cases. This is a view highly congruent with the cognitive processing approach to learning where students become active participants and builders of the content. It is through this understanding that, in this paper, the concept of visual communication in learning and teaching, its support in the learning process, as well as the role of visual literacy and visual intelligence during this process will be discussed and presented with visual illustrations.
\end{abstract}

Keywords: visual communication, instructional design, active learning, cognitive processing approach, visual literacy, visual intelligence, adult English as a second language (ESL) learning contexts

\section{Visual Communication Defined}

In their study regarding principles of design, Costello, Youngblood, and Youngblood (2012) referred to the design elements as the "ingredients used in making visual art" (p. 114). In support of adding visuals to the content of a rather text-rich instructional product, Mayer (2003) argued that "adding relevant graphics to words can be a powerful way to help learners engage in active learning. Overall, [one's] view of the cognitive stages of how learning works can influence [his/her] decisions about how to design instruction" (as cited in Clark \& Mayer, 2011, p. 79). According to Costello et al. (2012), visual communication is an area of study that "investigates the transmission of ideas and information through visual forms and symbol. On a deeper level, it also looks at the cognitive and affective processes that affect the way we perceive (or sense) visual stimuli" (p. 95). Communication through visuals is effective when content and form successfully interact with one another. In the instructional design (ID) terminology, the what (i.e., content) and how (i.e., form) of this message that the designer desires to communicate to the viewers involves an overlap of both elements that influence one's objective and subjective reality. That is, what one sees and perceives about the same message is highly affected by both the substance of that message and the manner in which it is transmitted to the audience, viewers, users, or in educational terminology, to learners. With respect to this, Hai-Jew (2010) posited that "Meanings may be interpreted at the top level of what is observed and depicted" (p. 270).

In regards to the interaction of content and form that plays a considerable role in the way one expresses or communicates his/her message, Costello et al. (2012) provided that while content is the "tangible essence of a work: the stories, ideas, and information that we exchange with others, form is the manner in which content is

Seda Khadimally, Ed.D. candidate, School of Advanced Studies (SAS), University of Phoenix. 
designed, packaged, and delivered for consumption" (p. 96). As such, prior to the design of any industrial or instructional product, designers should take several factors into account, including the scope of the instructional project (Clark \& Lyons, 2011), the learning context(s), learners' needs, previous knowledge, experience, educational background, differences in culture, language, visual and verbal intelligences, study skills, preferences, and others. Scholars engaged in the ID literature agree upon the positive impact of conveying meanings to students, trainees, users, or other target market, by including visual aids in instruction (e.g., lesson plans, module or unit-based agenda, weekly syllabi, course curricula, training products, or educational programs, etc.), which explains the extent to which visual communication has considerable effects on pedagogical frameworks, such as cognitive processing and active learning.

It is undoubtedly that both sight and perception are significantly affected by how powerfully a designer incorporates both textual and visual data into his/her design product, thereby, leaving not only an objectively impression on viewers or learners - and solely visually stimulating them — but, on a more profound and aesthetic level, lead them to deconstruct information, then construct their own meanings from the delivered message, and ultimately, learn by placing the information in their long-term memory (Larkin, 1998) based on the way they see the design and interpret it in their own reality, which supports ID scholars' approach to the effect of visual communications on learning. In support of this, Costello et al. (2012) asserted that in the absence of art, design is "either the humdrum repetition of familiar clichés or a wild scramble for novelty. Without the aesthetic, the computer is but a mindless speed machine, producing effects without substance, form without relevant content, or content without meaningful form" (p. 95). Aesthetics is a critical component of data visualization when creating meaningful content. This principle applies to learning and language learning, in particular. Clark and Mayer (2011) argued in favor of this view and stressed that "instructional designers should consider how words and pictures work together to create meaning for the learner" (p. 71).

\section{Visual Communication and Its Support on Learning}

If visual communication is one of visual aids, then it should be particularly pronounced in both formal and informal learning environments, regardless of the subject areas taught. Where learning and teaching activities are involved, the concept of visual communication should especially be pronounced. Effective communication supported with graphic images and added to the textual information can yield significantly positive learning outcomes on the part of the learners who find the content engaging, authentic (Reiser \& Dempsey, 2007), practical, applicable to real-life situations, technology-rich, collaborative, and fun. Also, those who design and deliver instructional products by use of an array of images, pictorials, drawings, graphics, charts, and other graphic imagery (Larkin, 1998) can achieve positive learning gains for their students, which they predetermine at the onset of the entire ID process.

Clark and Mayer (2011) clearly explained the support of visual communication in learning with their cognitive processing view. An approach to learning in which "providing relevant graphics with text is a proven method of fostering deeper cognitive processing in learners. In short, learning is facilitated when the graphics and text work together to communicate the instructional message" (p. 74). The power of visual representation of content should never be underestimated, especially given the importance to create learning environments wherein the active learning process is fostered. Instructors have the responsibility to guide their students' cognitive processing in learning, by allowing them to engage in active learning. It is through this type of 
learning that learners can make sense out of the material, and then reconstruct information. Needless to state, visuals have to play a tremendous role in this meaningful learning process, because they complement what words alone cannot accomplish on learners' active learning processes. According to Clark and Mayer (2011), "Multimedia presentations can encourage learners to engage in active learning, by mentally representing the material in words and in pictures and by mentally making connections between the pictorial and verbal representations" (p. 71). These visual representations are often included in online courses, textbooks, or in interactive, online, multimedia presentations that foster active learning for students. Multimedia presentations can additionally help learners engage in the active learning process, due to their ability to make connections between two types of representations: pictorial and verbal (Clark \& Mayer, 2011).

Use of visuals enriches the content delivered to learners, paving the way for authenticity and ingenuity of instruction. This facilitates learning, for research indicates that learners demonstrate higher interest in the message when they are given visuals rather than when they are presented text. Visuals particularly play an effective role in e-learning environments. Clark and Mayer (2011) posited that "in e-learning, [designers] can use a combination of text and audio, as well as still and motion visuals to communicate [their] content" (p. 17). The author focuses on static illustrations when they recommend that instructional designers that they add graphics to their instruction. The examples to these static illustrations include "drawings, charts, graphs, maps, or photos, and dynamic graphics, such as animation or video" (Clark \& Mayer, 2011, p. 70). Of course, what we mean by graphics included in an e-learning or distance learning setting, in a textbook, or in a traditional learning environment should not be there for decorative purposes, which Clark and Mayer (2011) called a "decorative graphic" (p. 71) that may sometimes be redundant, superfluous, disconnected from the text, or off-topic, making the text elusive or even complicated. On the other hand, adding graphics that are relevant and are associated with words can encourage learners to engage in active learning.

Anders (2010) provided that the type of visuals, as well as their quality and degree selected during the design process can have direct effects on how instruction will be delivered and how learning will be assessed (as cited in Hai-Jew, 2010). Today, there are an infinite number of learning/teaching environments - both formal and informal - which optimize the power of visuals and take literacy through visuals to the next level. Avatars or alteregos are demonstrated with innovative software, such as Tellagami, Alteregos, or Second Life (SL), the last one created by the Linden Labs, in addition to other virtual reality software. Cognitive science suggests that deeper semantic coding is required for learners' sense-making. That is, they need to be able to see the visual image and place information into their long-term memory with a certain level of preparedness, which, according to Hai-Jew (2010), is a view supporting human cognition, critical thinking, and problem-solving skills. Besides the frameworks and pedagogies related to imagery use in cognitive learning and information processing theory, Hai-Jew (2010) contended that there are also cultural implications for including visuals in learning and that both the Internet and the World Wide Web (WWW) culture have a high role in how designers make informed decisions about using these visual aids.

Instructional designers need to use graphics and other visual arts as appropriate media to transmit an appealing message that the users or learners can make meanings from. As such, where instructional media and design principles are concerned, designers need to consider ways to arrange and present two-dimensional and even three-dimensional visual elements (Costello et al., 2012) for learners or users of a particular design product. Clark and Mayer (2011) described graphics as "static illustrations, such as drawings, charts, graphs, maps, or photos, and dynamic graphics, such as animation or video. [They additionally] use the term 'multimedia presentation' 
to refer to any presentation that contains both words and graphics" (p. 70). Use of graphics in design of instruction should be made the major principle in today's digital classes where we, instructors, are now communicating data through two-dimensional images. After all, today's generation of learners is considered as "digital natives" (Prensky, 2010). They are also characterized in terms of the manner in which and how fast "they process information, the capacity of processing information that comes from different sources or screens simultaneously (multitasking), prioritizing image over text, living permanently in an online connected world, and attributing a predominantly recreational use to new technologies" (Aymerich-Franch \& Fedele, 2014, as cited in Benson \& Morgan, 2014, p. 56). Today's learners are seeking information that is relevant for them, those that are practical, and delivered fast before they move onto the next topic. As such, in digital learning environments where information is consumed in the matter of seconds, emphasis should be put on the inclusion of visual aids in the design and delivery of instruction. After all, graphs are engaging and students can actively participate in some of these interactive multimedia presentations together with the instructor both synchronously and asynchronously. It is thus crucial to underscore that use of graphics is immensely helpful in both design and delivery of the type of instruction that is engaging, motivational, interactive, collaborative, meaningful, and authentic for learners.

The substance and form duo proposed in the Deweyian line of thinking can be analogized to "what of a design and the how (the media) of that design" in learning/teaching settings. From an instructional viewpoint, the relationship among the Deweyian artist, the work of art, and the audience (Dewey, 1980) is no different from that among the teacher that is to design and deliver the content, the instructional content created in a visually beautiful manner, and the learner(s) that are to elicit meaning out of that content or message. It is through this triad that higher learning outcomes can be saliently evaluated.

\section{Role of Visual Literacy and Visual Intelligence in the Learning Process}

Clark and Lyons (2011) posited that visual literacy has been under realized for quite some time now when compared to overload of word usage to demonstrate certain content. Thus, in order to show the power of visuals that, according to the author, can leverage instructional design, they proposed readers diverse views of instructional visuals, a visual design model for systematic graphics planning, and planning of graphics to support transfer of learning. With this in mind, an exemplary unit lesson that is visually supported will be demonstrated below. The content delivered both in a formal learning setting and in an informal learning environment through online, interactive technologies is enriched by all graphic imagery incorporated into these tools.

According to Clark and Lyons (2011), again, how to best optimize use of graphics in order to illustrate content is of paramount importance. The author posited that including graphics pertinent to the content delivered assists with "fostering deeper cognitive processing in learners. In short, learning is facilitated when the graphics and text work together to communicate the instructional message" (p. 74). Thus, use of graphic images in teaching plays a very important role not only on a pragmatic level, but especially because these visual aids support learners' cognitive processing, which explains why they are congruent with the "cognitive processing theory," a learning approach held by Clark and Lyons (2011) in their text. In support of this, Larkin (1998) contended that the best way to demonstrate textual information or data in prose is through "presenting data in the form of graphs, diagrams, flow charts, and other graphics" (Para. 1). There are various forms of graphics that contain non-prose elements in order to accentuate the message of the designer/instructor who attempts to create and deliver an engaging, appealing message, data, or content by use of these elements. In regards to this, 
Larkin (1998) also provided that graphics can enable users - or learners - to obtain detailed information of what cannot be visually communicated through textual medium. Graphs, in short, are elements in any content that present non-textual data.

\section{How Visual Communication Can Support Learning in Adult ESL Contexts: A Formal Learning Community (The Academic Connections Online Lab-AC4 Online Lab)}

Much of research on student learning ties to the importance of student experiences in engaged learning. Through their experiences, students see value in the information being taught and learn how to transfer the knowledge to real-world practice. Today's digital era allows instructors to create learning environments for their students, which are rather active, socially networked, and collaborative. Those that are not necessarily found in traditional formal learning environments. When provided with visual data embedded in well-designed instruction, adult English as second language (ESL) learners become actively engaged in the learning process. Through effective instruction that includes all of the necessary elements of design, the second language learning process is made active, and scaffolding is fostered. It is noteworthy that continuous use of visual and verbal symbols that represent students' cultures which they can associate with their previous learning experiences not only facilitate their learning, but make the given content highly relevant, engaging, authentic, pragmatic, and entertaining for them.

In ESL classes, data visualization needs to be consistently promoted as necessary tools for effective learning and instruction. Authentic activities, cooperative learning via interactive class discussions, technology-mediated learning, guided participation, cognitive modeling, inner-speech, self-talk, reciprocal teaching, and peer tutoring (Ormrod, 2008) can also be practiced through well-designed second language instruction. As much as it has its own science, techniques, and its own methodology to teach with, the second language learning process or second language acquisition is also a form of art via which content is made relevant, authentic, contextualized, and most importantly, "meaningful."

\section{An Exemplary Unit Lesson in an Advanced Academic Preparation ESL Course}

With this unit lesson, students will understand how to use each online module in the AC4 online lab in order to take various integrated skills tasks, such as in writing and speaking, and to master their performances on what they have learnt about the topic, Microbiology, throughout the course. Gagne, Wager, Golas, and Keller (2005) pointed out that "the idea of mastery requires a change in thinking about instructional design as well as assessment" (p. 274). AC4 online course is a proper mode and rate of instruction in this adult ESL course as far as all of the understanding goals are concerned, because of two reasons:

1. AC4 online lab will not only help ESL students master their own learning throughout the course, but also lead them to get more hands-on with it than ever before;

2. The instructor of this course can more conveniently engage in further instructional practices, each time she provides her students with feedback on their academic performances. Also, she can practice further assessments and evaluations - and for her program-which, in turn, can explain the degree to which AC4 online is a very powerful mode of communication supported with an array of graphic images. The positive learning experience and value created with the AC4 online courseware can be felt both by the instructor and her students in this course. 


\section{Understanding and Application of War-Related Vocabulary Through AC4 Online Lab}

Over the course of six weeks, ESL students will understand and apply different meanings of war-related vocabulary (see Figure 1) in the microbiology unit, wherein they will learn about how they can fight diseases that are infectious. The students will also culminate their performances, by giving an individual five-minute impromptu speech in class or a 15-minute group-based oral report which they are to prepare at home, so they can showcase in class at the end of the unit. The learning goal with such impromptu speaking assignments is to help the students demonstrate their comprehensive understanding of the topic. As they showcase their culminating performances both during the semester and at the end of the course, students can go to YouTube and make their own videos by storytelling/narrating. They can also produce movies by using iMovie or other related movie making software. They can additionally design word clouds through tools, such as Wordle.net. Furthermore, the students can create blogs and wikis where they can upload several materials regarding Microbiology-related expressions, and then demonstrate them in class. They can also build mind/concept maps with a mind mapping tool, such as Inspiration.com, while using online synonmys and antonyms dictionaries, such as Visual Thesaurus.com, just-the-word.com (JTW), or ordandphrase.info/frequencyList.asp. For showcasing the root words and prefixes of academic vocabulary, they will learn until the end of this six-week course, and they can additionally refer to learnthat.org and several such other websites.

There are additional technologies by which ESL students in this course can perform their learning, such as PPT (Microsoft Office), Prezi.com (via web), Google Drive, Google Chat, WordPress.Org (for Blogs), Wetpaint,com (for Wikis), Skype, Face Time, LINE, and various other applications for voice and video calls. The fact that the students can find the opportunity to create their own designs, vocabulary lists, slides, wikis, and blogs both audibly and visually will help them excel at their learning at the end of the unit (i.e., Microbiology). The AC4 online lab and such innovative technologies can help the students achieve both content and skills-based mastery. Therefore, by using the modular, online component (AC4) of the textbook, the instructor will work with innovative modules in order to improve each skill. As their instructor and the moderator of the AC4 online lab, she will facilitate the learning environment for her adult ESL students, which will be conducive to their autonomous and mastery learning in each skill in the English language.

The instructor will then hand out a list of Microbiology-related vocabulary words to the students, those that correspond to the readings and listening excerpts built both in the text book, AC4, and also in its interactive, online course (AC4 online). Next, topic-related passages will be read, and vignettes with their transcripts will be audibly presented to them. Throughout this process, the students will be asked to review this vocabulary list, so their vocabulary skills can be assessed with a quick vocabulary test. Students are then to internalize some of the technical words necessary for them to be able to write a five-paragraph process essay about the topic, which will be their culminating writing project as the topic is concluded. The topic title of this take-home writing assignment will be as follows: How to Avoid the Spread of Infectious Diseases. Meanwhile, the students will be additionally assigned to complete take-home, online listening quizzes (see Figure 1), which they can take via the AC4 online, interactive course.

The ESL students will understand the purpose and implementation of all of the aforementioned educational technology tools commonly used for exploration, comprehension, demonstration, knowledge, acquisition, application, analysis, synthesis with alternative solutions, and evaluation (Bloom, 1968). With online, interactive reading and vocabulary tests on AC4 site (see Figures $2 \& 3$ for exemplary reading and 
vocabulary activities), the students will especially appreciate the similarities and differences between specific Microbiology-related terms and/or expressions, such as between infection and contagion, or among vulnerable to, resistant to, susceptible to, sensitive to, symptom, syndrome, attack, battle against, be overcome, combat, fight, epidemic, pandemic, etc..

\section{myacademicconnectionslabis 4}

\section{Listen to the passage. Choose the correct phrases to complete the text

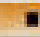

cause of disease of inlected with treated simply by \\ caused by essential to lead to}

A clean waver supply and eflicient water teatment ae $\quad \checkmark$ preventing at knds of ilnesses. Our water syshems can contain parasiles that $\checkmark$ schistosomiasis Schi-sto-so-mas-es, which is a disease that damages the bladder, the kidney, the fwer, and the intestines The Wond Heater Crganuaton estimales that 200 milion people may be $\quad v$ the paraste and that 200,000 de every year Now food preparation also affects out heath Gastroenteras, ga-stro-en-se-nits, which is a $\quad \checkmark$ the stomakh and the mestines, is $\checkmark$ improperty prepared foods reheated meat and seatood dishes, dary and bakery products. The Who stales that gastroenterts kills five to eight milion people per year, and is the lesding $\quad \checkmark$ death for children under the age of five. Ths, when gastroenterits can be $\checkmark$ retrydrabon

Figure 1. An online listening activity from the AC4 online lab.

As shown in Figure 1, this is an online, interactive listening activity from the online lab (i.e., AC4 online), which assists with assessing ESL students' understanding of the content of Unit 7 (i.e., Microbiology).

\section{myacademicconnectionslabo $\frac{35}{4} 4$}

Click on the button to read "Resistance to Antimicrobial Drugs." Choose the correct words to complete the text.

1) Among the major challenges facing microbiologists today are the $\square \checkmark$ presented by pathogens that are resistant to antimicrobial agents. We focus here on the development of resistance in populations of bacteria, but resistance to antimicrobials $\quad \checkmark v$ occur among viruses as well.

The process by which a resistant strain of bacteria develops is depicted in Figure 7.1. In the $\square \checkmark \checkmark$ of an antimicrobial drug, resistant cells are usually less $\checkmark$ than their normal neighbors because they must expend extra energy to maintain resistance to genes and proteins. Unde these circumstances, resistant cells remain the $\quad \checkmark$ in a population because they reproduce more slowly. However, when an antimicrobial agent is presentent, the majority of cêlls (which are $\quad v$ to the antimicrobial) is inhibited or diess, while the resistant cêlls continue to grow and $\checkmark \checkmark$, often more $\square \checkmark$ because they then face less competition. The result is that resistant cells soon $\square \checkmark$ the sensitive cells as the majority in the population. It should be noted that the $\quad \checkmark$ of the chemotherapeutic agent does not produce resistance, but instead $\checkmark$ the replication of resistant cells that were already $\quad \checkmark$ in the population.

Figure 2. An online reading activity from the AC4 online lab. 
As shown in Figure 2, the aim with this online, interactive reading activity is to support ESL students' thorough understanding of the topic, Resistance to Antimicrobial Drugs.

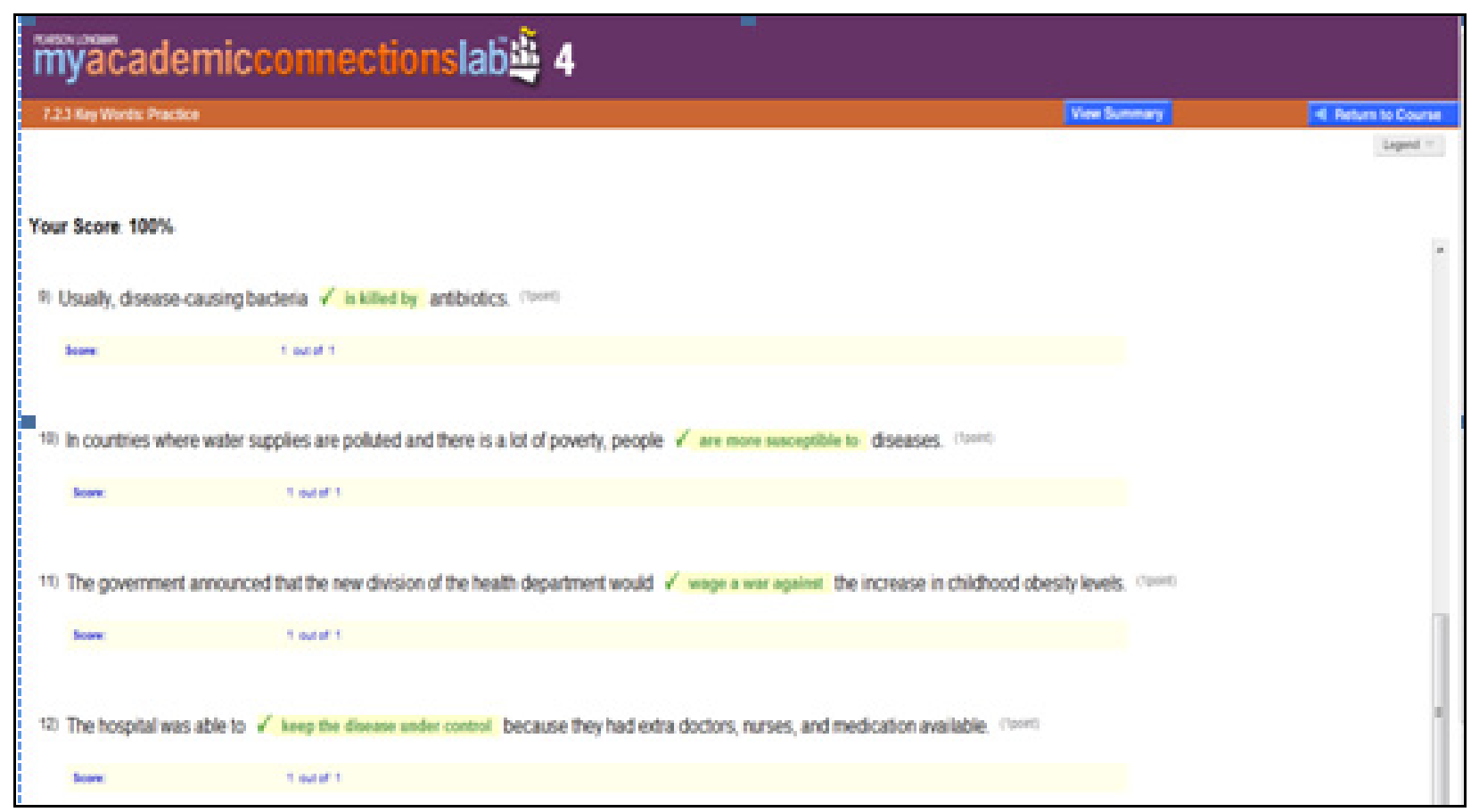

13) A disease that $\checkmark$ attacks the immune system is very dangerous because the body isn't able to fight against new diseases, and people get much sicker. (1point)

Score:

1 out of 1

14) People in the small village were $\checkmark$ overcome by a rare disease that couldn't be helped by medicine. (1point)

Score: 1 out of 1

Figure 3. An online vocabulary activity from the AC4 online lab.

As shown in Figure 3, with his gap-filling vocabulary activity from AC4 online lab, adult ESL students are asked to pair up and guess various war-related vocabulary words regarding the context (i.e., humans' fight with infectious diseases). The students are then to fill in the blanks with these words. This is a useful warm-up activity for students prior to their passing onto subsequent activities in other skills, such as reading and listening. The scaffolding component in this activity can especially lead to an understanding that the course instructor applies a constructivist learning approach.

Analyzing this unit lesson, it is thus possible to assert that the instructor of this adult ESL academic preparation course has adopted and implemented a constructivist approach to her students' learning processes - from design to delivery to evaluation. By integrating social constructivism (Vygotsky, 1978) into their instruction, therefore, ESL teachers delivering the subject matter to older adolescents and/or adults can help their students transform into self-directed learners and a knowledge-building community. The ideal learning environment can be described as one in which English language learning is made active, and scaffolding is fostered. Use of cultural and verbal symbols is promoted as a necessary tool for learning and 
teaching. Authentic activities, cooperative learning via interactive class discussions, technology-mediated learning, guided participation, cognitive modeling, inner-speech, self-talk, reciprocal teaching, and peer tutoring (Ormrod, 2008) can also be practiced through this learning pedagogy. As a result, with the implementation of social constructivism in adult ESL classroom applications, linguistically and culturally diverse ESL students' learning can be improved.

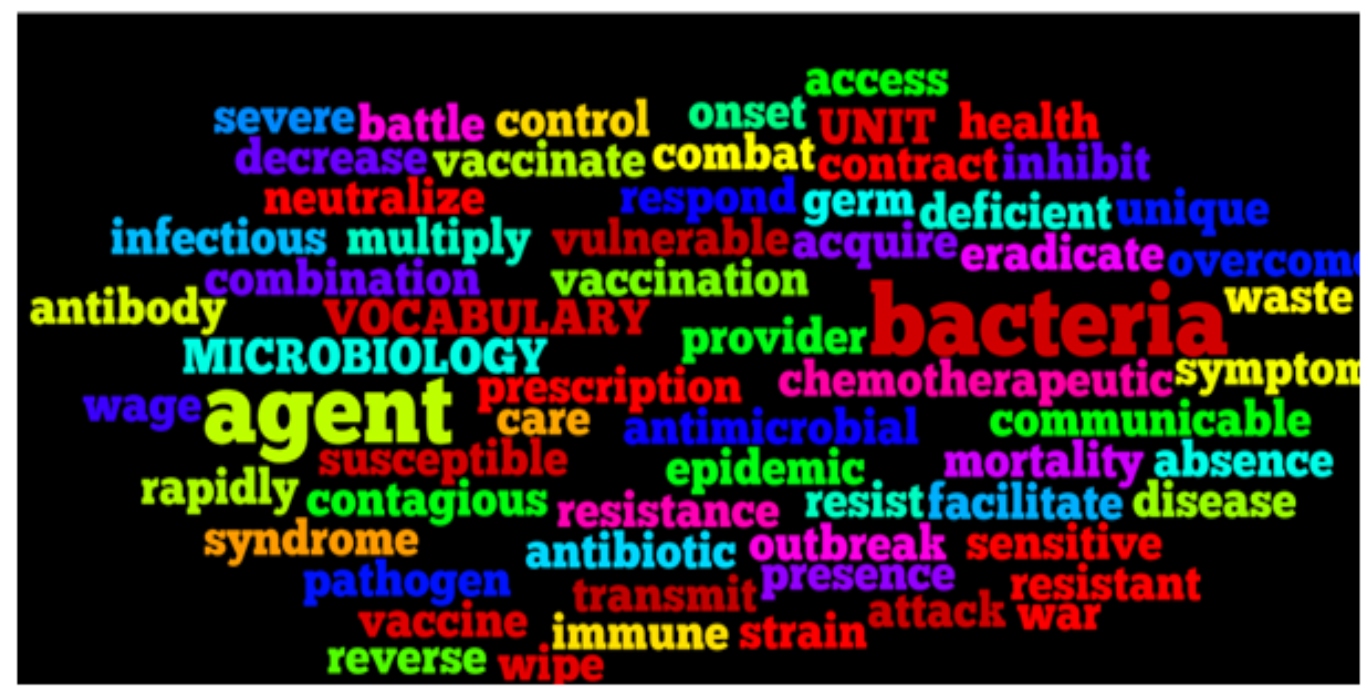

Figure 4. Unit 7 vocabulary words via Wordle.net, an online word cloud tool.

As shown in Figure 4, by use of this tool, the most frequently used advanced academic words derived from the unit vocabulary are designed and presented to ESL students in a way that they will gradually begin to digest these words, and build upon them as they engage in various vocabulary, reading, writing, listening, and speaking activities and tests. What stands out by use of this technology is that the students will ultimately end up mastering academic vocabulary pertinent to the topic, Fighting Infectious Diseases.

\section{Creating Meaningful Learning via Social Media (Facebook) and Mobile Technologies With an Informal Learning Community}

A plethora online social network sites (SNSs) have emerged due to technological advances today. Some of these are Facebook, Myspace, Twitter, wikis, blogs, and virtual worlds (Bicen \& Cavus, 2011, as cited in Benson \& Morgan, 2014). Embracing social media tools in the non-traditional, online classroom environment is significant, for they are very powerful tools of learning, and today's net generation (Glenn, 2000) recognizes their own important role in helping "shape the future of this increasingly global, interconnected society" (Wesch, 2008, p. 7, as cited in Yildiz \& Scharaldi, 2015, p. 259). Through SNSs, students can create new forms of expression and new rules for social behavior. They can share their creative works, such as a video they produced, an online, interactive game they designed, or a SNS they customized based on their personal preferences. They can then receive feedback and response both from their peers and their instructors online. This type of feedback is often immediate, and includes breadth of information. Such information exchange greatly adds to these learners' media skills and knowledge repertoire, particularly providing them with the ability to learn, create, and share at their own pace and based on their own learning needs and personal learning styles, which clearly explains that the social media and the digital world are very likely to lower transactional barriers to students' autonomous learning in the digital age. 
Visual communication on Facebook has considerable potential for adult learners and is cost-effective, because this platform not only supports the type of learning that is socially networked, but also knowledge that is constructed by learners "recreating the content themselves." Considering the importance of creating meaningful and relevant learning experiences for students both inside and outside of the classroom environment, Ryokai (2012) presented a mobile technology-based learning (mobile learning [m-learning]) model which that not only sustains a personal connection between the student and the learning material, but enables a social constructivist approach to learning, which aligns with Vygotsky's aforementioned learning pedagogy.

Similarly, Park (2011) presented a four-type pedagogical framework of m-learning within the distance education context, including high transactional distance and socialized m-learning activity, high transactional distance and individualized m-learning activity, "low transactional distance and socialized m-learning activity" (see Figures 5-8), and finally, "low transactional distance and individualized learning activity." Finally, with a highly constructivist, learner-oriented, iterative, informal, and personal approach to learning, Naismith, Lonsdale, Vavoula, and Sharples (2004) proposed a conceptual framework that is situated and based on collaborative work that explains the extent to which mobile technology assisted practices are highly conducive to andragogical learning model and the constructivist learning theory.

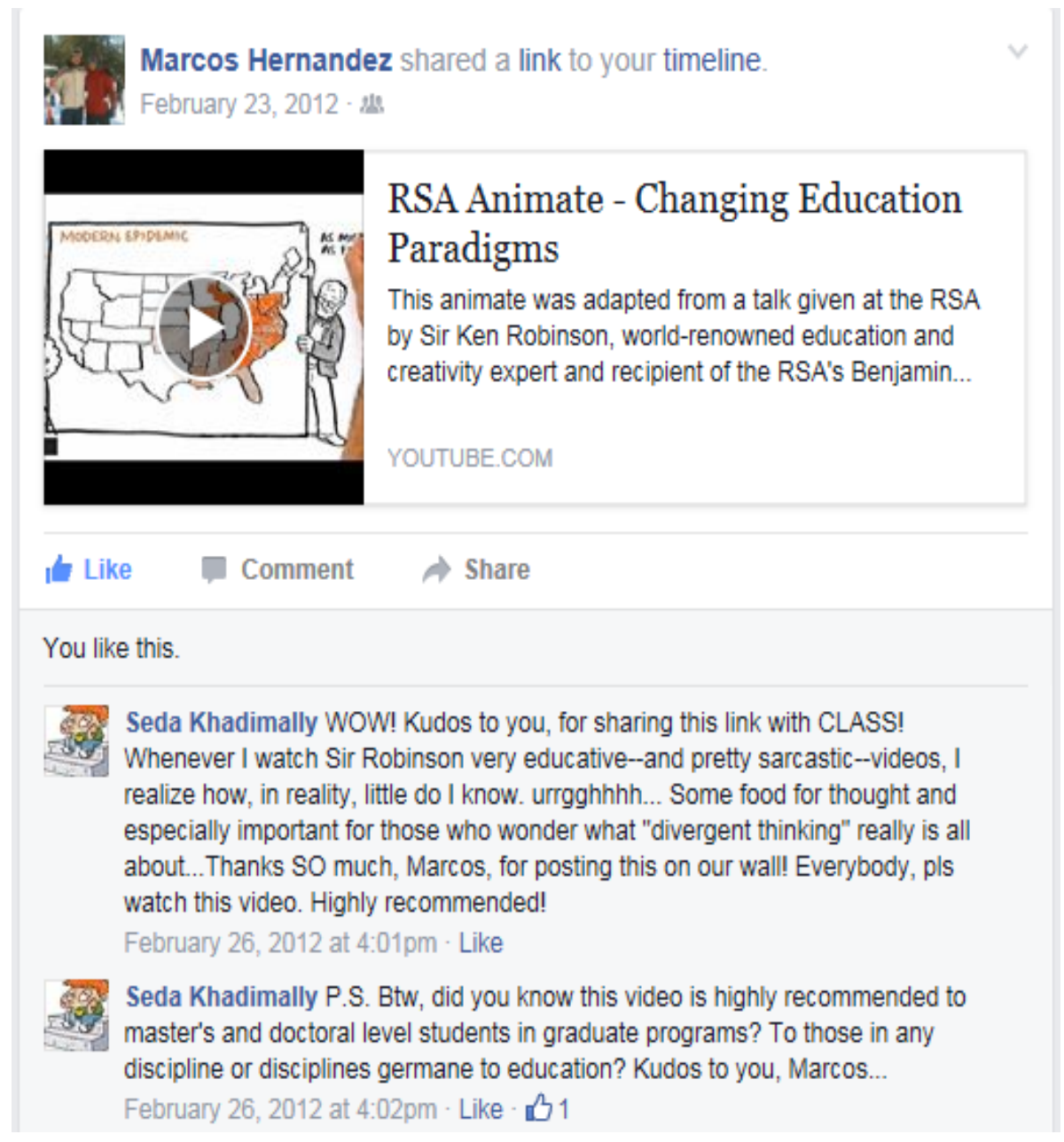


Freedom Beta > Seda Khadimally

February 21, $2012 \cdot$ s

Thank you Mr. Pashar for your excellent conference and professionalism. The topic was absolutely interesting. Thank you Seda you are amazing. ILU
1 Like
Comment

You and 2 others like this.

Seda Khadimally Thank YOU, guys, and especially for your wonderful questions and comments, Libertad:->)

February 21, 2012 at 8:04pm - Like - 12

Romina Anabella Vasconi Hi ! Did you receive my message seda?

February 21, 2012 at 8:30pm - Like

\section{Asya Özkızılcık > Seda Khadimally}

February 21, 2012 - Houston, TX - dy

Hiii!!!

I've forgotten how many references we should use for our annotated bibliography. Is it ONE or two? :))) ONE or two? :)) ONE or two? (:) (:): :-)) :-)))

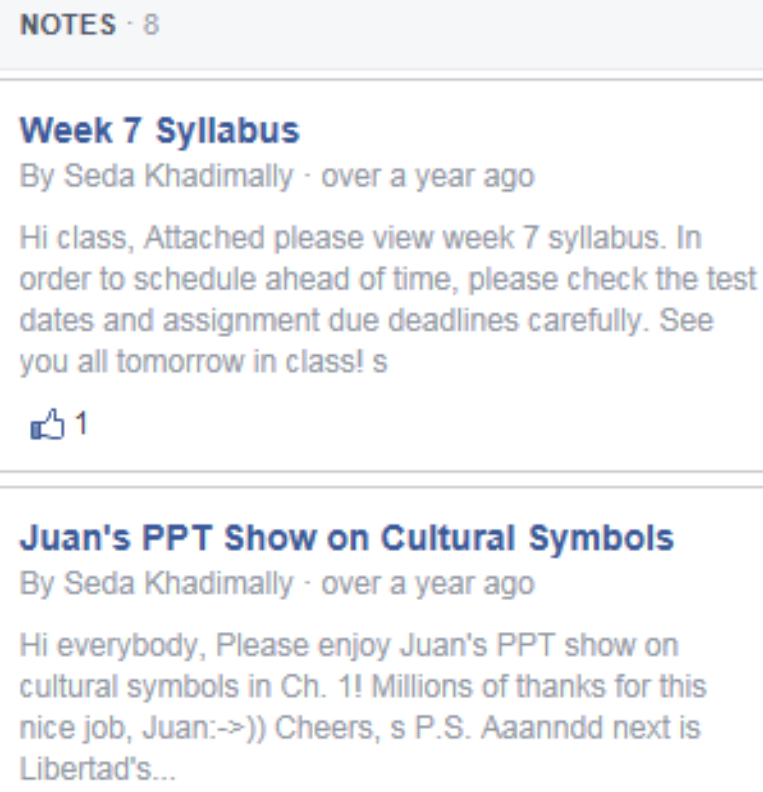




\section{Seda Khadimally}

February $26,2012 \cdot \boldsymbol{s} \cdot$

\section{$\star \star \star$ IMPORTANT !}

These are the programs that I would like to see as tools that assisted you with your ePortfolio showcase. With that said, please feel free, however, to come up with yours. Consult with your team members and discuss which one is best for your particular skill presentation, assignment choice, and the like. please keep in mind to work with each of your team members in a collaborative effort; be creative and ingenious; keep originality in your presentation, and do NOT PORGET TO CITE as you are presenting the written work! Speak slowly and eloquently, use your gestures less and yet intonations more. Also, ALWAYs remember to do the opening and closing speeches! IMPRESS ME with your knowledge and newly acquired repertoire of academic vocabulary, advanced listening, and most importantly, research writing! I cannot wait to watch your creative and ingenious works.

Good luck, al10

It Like Comment $\Rightarrow$ Share

\section{Seda Khadimally}

February 26, $2012 \cdot$ Houston, TX - $\mathbf{4} \boldsymbol{\nabla}$

Note our group's Skype User Name:

AAP Jan-Feb 2012

1 included everybody in this group.

\begin{tabular}{|c|c|c|}
\hline It Like & Comment & \\
\hline त्रs & Write a comment... & 이 (-) \\
\hline
\end{tabular}

CLASS, I will bring a hard copy of everything I have written on this wall today in detail! NO worries, in case you have no access to the Internet in the next couple of days. At least, you can have a hard copy of a to-do list until Wednesday morning. My students NEVER get lost:-)

Cheers,... See More

It Like Comment $\Rightarrow$ Share

Figure 5-8. Adult ESL students' use of social media (i.e., Facebook) as an informal learning community. 
As shown in Figure 5-8, all of these figures above demonstrate adult ESL students' online interactions on social media (i.e., Facebook) as an informal learning community in an advanced level academic preparation course.

Students' and instructor's social media use in this particular adult ESL class facilitates their positive communication and dialogue. Furthermore, with this example of an informal learning community, it is possible to observe "the level of unstructured and yet continuous, dialogic interplay" between the instructor of this course and her adult ESL students. Such a dialogic process not only indicates that this is a rather informal learning context, but also demonstrates what Moore (2007) called positive and encouraging teaching behaviors for the entire learner group in this adult ESL academic preparation course. Most importantly, the fact that all of the assignments, tasks, class schedule, as well as class reminders are designed and delivered in a guided manner can lead one to appreciate the type of learning and teaching environment that is constructivist in nature. Given this scaffolding aspect of the course content that is designed, developed, and delivered under the instructor's initial guidance, and based on the type of feedback she provides both positively and immediately - although asynchronously — one can see the constructivist approach to learning adopted and implemented by the course instructor in this academic preparation ESL course.

\section{Conclusion}

Vygotsky (1978) said, "Well-designed instruction is like a magnet" (as cited in Snowman \& Biehler, 2006, p. 49). Drawing on this, it is noteworthy that visual communications play a fundamental role in the instructional design, learning, and teaching process. The essential role of visual communications perceived to lead to improved visual literacy and visual intelligence is especially evident in learning environments where social media tools are involved. Based on the example regarding a specific social media technology (i.e., Facebook) implemented in an academic preparation adult ESL course, the considerable potential and advantages of visual communications and visual literacy were observed under close lens. In this paper, the substantive impact of the concept of visual communications in second/foreign language learning and teaching contexts was the focus of discussion, particularly because it not only constitutes a time-efficient and cost-effective platform, but supports the type of learning that is socially and digitally networked - not to mention the fact that knowledge and meaning are constructed by learners recreating the content themselves. Eventually, any time a visually rich and technologically savvy instructional product is designed and prepared to be delivered to target learners, it should facilitate them with a blend of formal and informal learning environments in which the social constructivist approach to learning is fostered, critical and analytical thinking skills are supported, interaction, active participation, collaborative knowledge building, meaning making, and networked learning are promoted, as well as learning objectives predetermined at the onset of the design are successfully achieved.

\section{References}

Benson, V., \& Morgan, S. (2014). Cutting-Edge technologies and social media use in higher education (pp. 1-436). Hershey, P.A.: IGI Global. doi:10.4018/978-1-4666-5174-6

Bloom, B. S. (1968). Learning for mastery. Evaluation Comment, 1(2), 1-5.

Clark, R. C., \& Lyons, C. (2011). Graphics for learning: Proven guidelines for planning, designing, and evaluating visuals in training materials (2nd ed.). San Francisco, C.A.: Pfeiffer.

Clark, R. C., \& Mayer, R. E. (2011). E-learning and the science of instruction (3rd ed.). Hoboken, N.J.: Pfeiffer.

Costello, V., Youngblood, S. A., \& Youngblood, N. E. (2012). Multimedia foundations: Core concepts for digital design. Burlington, M.A.: Taylor \& Francis. 
Dewey, J. (1980). Art as experience. New York, N.Y.: Penguin Group.

Gagne, R. M., Wager, W. W., Golas, K. C., \& Keller. J. M. (2005). Principles of instructional design (5th ed.). Mason, O.H.: Cengage Learning.

Glenn, J. M. (2000). Teaching the net generation. Business Education Forum, 54(3), 6-14.

Hai-Jew, S. (2010). Digital imagery and informational graphics in e-learning: Maximizing visual technologies. Hershey, P.A.: IGI Global.

Issa, T., Isaias, P., \& Kommers, P. (2014). Multicultural awareness and technology in higher education: Global perspectives (pp. 1-449). Hershey, P.A.: IGI Global. doi:10.4018/978-1-4666-5876-9

Larkin, G. (1998). Notes for a lecture on types of graphics: Graphics in technical communication. In ENG 302 course, Northern Arizona University. Retrieved from http://jan.ucc.nau.edu/ larkin/eng302/class/rhetoric/graphics/lesson1-4-2.html

Mayer, R. E. (2003). Learning and instruction. Upper Saddle River, N.J.: Merrill Prentice Hall.

Moore, M. (2007). The theory of transactional distance. In M. Moore (Ed.), Handbook of distance education (2nd ed.). Mahwah, N.J.: Erlbaum.

Naismith, L., Lonsdale, P., Vavoula, G., \& Sharples, M. (2004). Literature review in mobile technologies and learning. Retrieved from http://telearn.archives-ouvertes.fr/docs/00/19/01/43/PDF/Naismith_2004.pdf

Ormrod, J. (2008). Human learning (5th ed.). Upper Saddle River, N.J.: Pearson/Merrill Prentice Hall.

Park, Y. (2011). A pedagogical framework for mobile learning: Categorizing educational applications of mobile technologies into four types. International Review of Research in Open and Distance Learning, 12(2).

Prensky, M. (2010). Teaching digital natives: Partnering for real learning. Thousand Oaks, C.A.: Corwin.

Reiser, R. A., \& Dempsey, J. V. (2007). Trends and issues in instructional design and technology (4th ed.). Columbus, O.H.: Pearson.

Ryokai, K. (2012). Mobile learning with the engineering pathway digital library. International Journal of Engineering Education, 28(5), 1119-1126.

Snowman, J., \& Biehler, R. (2006). Psychology applied to teaching (11th ed.). M.A.: Houghton Mifflin Company.

Uzunboylu, H., Cavus, N., \& Ercag, E. (2009). Using mobile learning to increase environmental awareness. Computers \& Education, 52, 381-389. doi:10.1016/j.compedu.2008.09.008

Vavoula, G. N., \& Sharples, M. (2008). Challenges in evaluating mobile informal learning. In Proceedings of the m-Learn 2008 Conference (pp. 296-303). Wolverhampton, England.

Vygotsky, L. S. (1978). Mind and society: The development of higher mental processes. Cambridge, M.A.: Harvard University Press.

Yildiz, M. N., \& Scharaldi, K. (2015). Integrating mobile technologies in multicultural multilingual multimedia projects. In J. Keengwe, \& M. Maxfield (Eds.), Advancing higher education with mobile learning technologies: Cases, trends, and inquiry-based methods (pp. 254-277). Hershey, P.A.: IGI Global. 